\title{
Education 4.0: Value of Subjectivity in Meeting with Technology
}

\author{
Educação 4.0: Valor da Subjetividade no Encontro com a Tecnologia \\ Educación 4.0: Valor de la Subjetividad en el Encuentro con la Tecnología
}

Received: 01/20/2022 | Reviewed: 01/24/2022 | Accept: 01/29/2022 | Published: 01/31/2022

Valéria Marques de Oliveira

ORCID: https://orcid.org/0000-0003-4821-123X Federal Rural University of Rio de Janeiro, Brazil

E-mail: valeriamarques@ufrrj.br

Hérica Landi de Brito

ORCID: https://orcid.org/0000-0002-0629-5634 Centro Universitário Alves Faria, Brazil E-mail: hericalb@gmail.com

Wilson de Jesus Beserra Almeida

ORCID: https://orcid.org/0000-0003-4746-2387

Centro Universitário Alves Faria, Brazil

E-mail: wilson.almeida@unialfa.com.br

Marcus Vinicius Barbosa

ORCID: https://orcid.org/0000-0003-0131-0257

Federal Rural University of Rio de Janeiro, Brazil

E-mail: marcus.barbosa1979@gmail.com

Alessandro Simões Marinho

ORCID: https://orcid.org/0000-0002-4672-9636

Federal Rural University of Rio de Janeiro, Brazil

E-mail: aless.simoes@gmail.com

\begin{abstract}
Industry 4.0 is based on digital technological advances that demand educational processes that develop people to act in line with this scenario. Based on the ecological and systemic view, mainly on the concepts of bidirectionality and self-eco-organization, the aim of this text is to reflect on the effect of the connection between education 4.0 and industry 4.0 in Brazil in the constitution of subjectivity. Narrative review was applied in the fields of History and Philosophy of Education, Brazilian Industrialization and Educational and Organizational Psychology, to support a Brazilian socio-historical reading of the four industrial revolutions and their parallel with education, the influence on the Brazilian subjective position is inferred. Ethically positioned in terms of human and professional training, it is argued that technological advances should be at the service of human beings and not the other way around. In this sense, we conclude that dialogic and emancipatory education, aware of its subjective influence, has an important role in social justice. The appreciation of subjectivity supported by the construction of autonomy and thought authorship can serve as key elements to educational success in connection with Industry 4.0.
\end{abstract}

Keywords: Education 4.0; Autonomy of thought; Thought authorship.

\section{Resumo}

A indústria 4.0 pauta-se no avanço tecnológico digital que demanda processos educacionais que desenvolvam pessoas para atuarem em consonância a este cenário. Baseado na visão ecológica e sistêmica, principalmente nos conceitos de bidirecionalidade e autoecoorganização, o objetivo deste texto é refletir sobre o efeito da conexão entre educação $4.0 \mathrm{e}$ indústria 4.0 brasileiras na constituição da subjetividade. Aplicou-se a revisão narrativa nos campos da História e Filosofia da Educação, Industrialização brasileira e Psicologia da Educação e Organizacional, para sustentar uma leitura sócio-histórica brasileira das quatro revoluções industriais e de seu paralelo com a educação, infere-se a influência na posição subjetiva brasileira. Posicionados eticamente quanto à formação humana e profissional, defendese que o avanço tecnológico deva estar a serviço do ser humano e não o contrário. Neste sentido, concluímos que a educação dialógica e emancipadora consciente de sua influência subjetiva tem importante papel na justiça social. A valorização da subjetividade apoiada na construção da autonomia e autoria de pensamento podem servir como elementos chave ao sucesso educacional em conexão com a Indústria 4.0.

Palavras-chave: Educação 4.0; Autonomia de pensamento; Autoria de pensamento.

\section{Resumen}

La Industria 4.0 se basa en avances tecnológicos digitales que demandan procesos educativos que desarrollen a las personas para actuar en consonancia con este escenario. Con base en la visión ecológica y sistémica, principalmente en los conceptos de bidireccionalidad y auto-eco-organización, el objetivo de este texto es reflexionar sobre el efecto 
de la conexión entre educación 4.0 e industria 4.0 en Brasil en la constitución de la subjetividad. La revisión narrativa se aplicó en los campos de Historia y Filosofía de la Educación, Industrialización Brasileña y Psicología Educativa y Organizacional, para sustentar una lectura sociohistórica brasileña de las cuatro revoluciones industriales y su paralelo con la educación, se infiere la influencia sobre la posición subjetiva brasileña. Posicionado éticamente en materia de formación humana y profesional, se argumenta que el avance tecnológico debe estar al servicio del ser humano y no al revés. En este sentido, concluimos que la educación dialógica y emancipadora, consciente de su influencia subjetiva, tiene un papel importante en la justicia social. La apreciación de la subjetividad sustentada en la construcción de la autonomía y la autoría del pensamiento pueden servir como elementos clave para el éxito educativo en conexión con la Industria 4.0.

Palabras clave: Educación 4.0; Autonomía de pensamiento; Autoría de pensamiento.

\section{Introduction}

The nickname "Industry 4.0" was created by the German government in 2011 to highlight the use of high technology in German industry (Herman et al., 2015), with reflections on automation, control, information technology, applied to Production processes. In fact, today's society has never been so dependent on technological resources, as experienced in current times, especially with the ubiquity of Digital Information and Communication Technologies (TDIC).

Industry 4.0 demands an Education 4.0, and, without it, its existence is impossible, as it is necessary to form a new personal and professional profile that incorporates technological advances from school to corporate education from a more agile, updated perspective. and innovative. human being is the main element in the context of training for work and for their life in society, this cannot be reduced to a piece of maneuver in Industry 4.0. Subjectivity, as a process of constitution of the psyche, allows man to appropriate the productions of humanity from certain life conditions and the development of unique individuals (Silva, 2009). Therefore, it must be recognized and praised, and not diminished in the face of technological innovations.

In this sense, human subjectivity contemplates idiographic (individual aspect) and nomothetic (generalizable aspect) aspects, respects both singularity, particularity and universality. In this way, the way each subject lives their history is unique, but simultaneously, they share symbolic aspects present in socio-historical contexts with their group and with broader aspects present in their time (Furtado et al., 2017).

Gergen (1991 apud Rüdiger, 2000) describes that, on the one hand, the advancement of communication technologies puts the notion of self at risk, and on the other hand, individual identity is created and recreated through relationships. "It will be up to conscious human praxis, whenever possible, to decide the dominant direction that all this technological movement will take, but whose nature, ultimately, is social and historical" (Rüdiger, 2000, p. 194). Every type of social participation implies responsibility in taking decisions. For this decision-making, we need to reflect on who we are and what world we want.

\section{Methodology}

This text proposes a critical analysis of the value of subjectivity in the encounter with technology, based on the Brazilian historical path of Industrial and Education from its beginnings to phase 4.0, converging on the reflection on the value of subjectivity in line with the technology. To this end, the narrative review was used because it is a more open and general qualitative research methodology that seeks to have a general and updated view of the topic studied (Ribeiro, 2014). Without prior definition of time coverage in the researched topic, the selection criterion filtered the data on the phases and history of Industry and Education contextualized and the political-economic relations.

The ecological and systemic perspective was applied in this review, as it favors the understanding of the effect of interactional processes on human development (Barreto, 2016). This made possible the critical analysis of two concepts that support the data web: a) bidirectionality (Bronfenbrenner \& Morris, 1998), mutual influence between subject and world, and b) self-eco-organization (Morin, 2007), internal process of equilibrium triggered in the interaction. 


\section{Relationship Between Industry and Education in Brazil: From the Beginnings of the 1.0 Revolution to the Present 4.0}

The categorization of the four Industrial Revolutions in Brazil was the axis chosen for reading the current Brazilian scenario regarding the connection between the movements of Industry 4.0 and Education 4.0. The term revolution is used because it refers to a major change of course, characteristically disruptive, with consequences that go beyond technological and business advancement itself. The indicated dates must be considered as approximate to glimpse a temporal panorama, since the changes occur contextually, with comings and goings, and not in an abrupt or linear way.

Although there are occasional incursions of the Brazilian industrial experience since the First Industrial Revolution, industrialization actually begins to take shape from the Second Revolution, when Brazilian education also gains a new direction. However, for a better understanding, we will make scores from the Brazilian periods of Reign and Empire, until reaching the Republic period of the present day.

\subsection{Industry 1.0 \& Education 1.0}

The First Industrial Revolution began in England in the second half of the 18th century, between 1760-1840, and lasted until the 19th century. It was driven by the Enlightenment values of freedom and equality appropriated by the bourgeoisie, which had come to power with capital accumulation. The world had experienced great social transformations such as the American Revolution and the French Revolution. These were favorable conditions for the transition from feudalism to capitalism and for the establishment of industries.

Its main feature was the use of the steam engine in the textile industry, in shipbuilding and in train transport. This mechanization was a milestone in the process of transition from artisanal production to industrial production. The machine has replaced human strength and social know-how. Craftsmen ceased to dominate the production process and became wage labor.

Mechanization did not require instruction, the living conditions of workers were inhumane (Gotardo \& Favaro, 2019). Education was for the elite, led by religious to children. These, in addition to being literate, studied riding, values, norms and government manuals. The idea of the professor as the center of the educational proposal and transmitter of knowledge was strengthened. Meanwhile, living in a society of oral tradition, the people remained illiterate, their knowledge was based on experience, common sense and traditions. Mometti (2021) considers that only later, in the 19th century, there was an integration between the educational process and industrialization.

How was Brazil at the time of the First Industrial Revolution? Since 1500, with the arrival of the Portuguese, the social imaginary was marked by subservience and fascination with what was foreign. Our land, as an exploration colony, played the role of provider of raw materials and payer of taxes for the Portuguese Crown. Its agricultural tradition lasted for many centuries, and any initiative for its own development, including intellectual ones, was curtailed as threatening by the State. One can find records of small production of fabric and iron only for local consumption, with a discreet incursion into shipbuilding. However, in 1785, any action of this nature was prohibited (Arquivo Nacional, 2021 [1785], to avoid competition and uprisings. The only permitted manufactures produced thick cotton fabrics for slaves' clothes.

Along with the Portuguese, the Jesuits arrived with the Society of Jesus, in the Counter-Reformation movement. These dominated education for nearly two centuries. With great emphasis given to classical texts, to rhetoric, in a conservative way with a focus on memorization, away from everyday life, he educated the boys of the privileged class (for administrative positions) and the indigenous (for catechization). This period became known as Brazilian pedagogy (Saviani, 2007).

The Pombaline Reform, in 1759, expelled the Jesuits from Portugal, Brazil and Angola, with the intention of joining the European Enlightenment movement. With the influence of liberalism and positivism, teaching becomes secular (Saviani, 
2007). This had a double impact: negative, since the Jesuits had the educational systematization, and positive, by assuming itself as an Educating State, Portugal inaugurated a new form of teaching that transformed the "almost divine" concept of teaching, into a profession, and instituted the professor as a civil servant. However, the first professors, trained through contact with the Jesuits, followed the same rigor. The objective of education remained focused mainly on training the future managers of society.

Although the same reform was extended to Brazil, its unfolding here was very different, resulting in the almost total destruction of the scarce existing education as the government was exercised from outside. This reinforced the imagination of some that the good was abroad, and here it boiled down to exploration. Soon, the more affluent went to study abroad.

At the beginning of the 19th century, two historical facts marked education in Brazil: the arrival of the Royal Family in 1808 and independence proclaimed in 1822. In 1808, with the act of elevating Brazil to the United Kingdom and opening the ports to friendly nations, other actions were taken to encourage local advancement, such as granting industrial privileges to those who invent machines and direct investments from the Crown. However, we were still dependent on English products.

Independence brought the attempt to continue the ties with the outside that would guarantee the inflow of resources in the country. In this period, society remained basically rural. In 1838, the first public secondary school was founded in Rio de Janeiro, Pedro II School's. In the capital, a weak movement of public elementary education began, which when it existed, was the result of specific initiatives by provincial governments, private tutors or priests (Schwartzman, 2005). There was no government commitment to education for the people, as it was a privilege and not a social right.

The period of liberal capitalism covers the entire 19th century, decisions in favor of the market prevail, even directing civil and political rights (Santos, 1991). Araújo (2012) discusses the awakening of interest in the subjectivity of the salaried worker in the First Industrial Revolution, initially changing the idea that work was something less performed by slaves, for example. It should be noted that the abolition of slavery in Brazil took place only in 1888, one year before the Proclamation of the Republic. Brazil was a basically rural society, with a discrepancy in the quality of life (and rights and duties) between the royal family, nobility, peasants/small merchants and slaves.

Through submission (physical and psychological violence) servitude was preserved. Cultural resistance and local creation/production movements were muffled and prohibited. Education aimed at the nobility and future leaders served to naturalize the maintenance of social inequality. The image of the surviving native people was disseminated as primitive in the Eurocentric perspective, and slavery and social inequality were naturalized, more than that, scientifically justified (Silva, 2014). Education served to regulate the State and maintain hegemonic power.

Expressions of individual subjectivity were covered up and discredited in the name of idealized national subjectivity. The fruits of humanity's productions were not equitably distributed. While managers and the privileged class were joined by the arrogance that masked the fear of being different, other Brazilians continued to feel the pressure of submission experienced in the colonial and imperial periods, even in the republican period, as a result of the economy of dependence on dominant central capital (Conforti, 2017). Living conditions were quite different between royalty/nobility and the general population. Between the feeling of belonging and humiliation. Haroche (2009) reveals that the different forms of colonization invoke the feeling of loss, denial of self-worth and depersonalization. As a response of the stigmatized, it was present from escapes, revolts, denial of work, disobedience, formation of Quilombos, religious syncretism to submission and identification with the oppressor (Furtado et al., 2014).

\subsection{Industry 2.0 \& Education 2.0}

The Second Industrial Revolution began at the end of the 19th century, in the period between 1860-1900 and lasted until the 20th century. The power of water vapor was replaced by electrification. The main inventions were electricity and the 
combustion engine, which made automation and mass production possible. English hegemony was replaced by other nations such as Germany and the USA. This period marked the rise of European industry, which emerged in economic and political power. Until many of his efforts were diluted with the beginning of the Second World War, which shifted the strategic focus of US policies to Latin America, especially to Brazil.

The Fordist (production line) and Taylorist (division of labor) production system marked this era. With greater production and better technological resources, there was a need to remodel the educational process, for a side of utility and applicability in production (Mometti, 2021). From the end of the 19th century, formal education was recommended for workers with the minimum (reading, writing, and calculating) to raise the moral and civic level, and favor social control (Gotardo, \& Favaro, 2019).

In Brazil, the Proclamation of the Republic in 1889 was influenced by the strengthening of liberal thought and the search for "modernity". With these Enlightenment ideas began the project of universalization of education. Although the focus was on industrialization, colonial thinking, in a way, remained on education. The professor continued as the center of the process and responsible for the formation of this "modern man". It was up to him to choose and teach the contents, with an emphasis on reproduction and memorization.

Continuing the strengthening of the modern prerogative of the positive meaning of worker, Araujo (2012) points out that Mayo begins the management of worker subjectivity with the movement of human relations. However, effectively, the cooperation valued was not in the interests of the worker, but of the company. With the growing intention of modernity, knowledge of psychology was also applied at school, as developed by authors such as James (observation of school life), Dewey (child as an active learner), Thorndike (importance of evaluation and measurement of learning based on scientific principles) (Santrock, 2009).

The strongest movement in the 1920s was denominated Escola Novista (New education), which argued against traditional pedagogy and emphasized the psychological aspects of the teaching-learning process. Helena Antipoff, a disciple of Claparède, organized actions to train professors and valued child psychology. This phase became known as pedagogical optimism, in which education was understood as a way out of social problems (Santrock, 2009).

After the First World War, the industrialization of the economy was promoted. The State, therefore, positioned the school as a central apparatus for the formation of citizens and the advancement of national development. In Brazil, this phase gained strength in the 1930s with Getúlio Vargas, who made elementary education mandatory and universal. In the developmental state, the school, as a national priority, assumes the role of training for the world of work. There was a concern with the process of building national identity, and scientific racism contributed to this area, but given its weaknesses, a new field centered on culture was being formed (Silva, 2014).

The creation of the National Education Council, responsible for organizing the National Education Plan, the National Institute of Pedagogical Studies, and the establishment of the Capanema Reform, was responsible for the reorganization of the Brazilian education system. In response to the aspirations of the new and thriving industrial model, through Law 4073 of 01/30/1942 the Organic Law of Industrial Education was instituted, aimed at the working class that incorporated the mass of workers who needed to be able to work in the industrial platinum in the country (Brito, 2006).

With the implementation of Vargas' policies, according to Oliveira (2003), the Federal Council of Foreign Trade CFCE was created in 1936, which would produce a rupture with regard to the effects of capital accumulation in the country and State intervention, in a redefinition of its role, transforming the dynamics of the urban-industrial pole into a dynamic axis of the economy in a process of transition. Added to this, Oliveira (2003, p.30) points out that this relationship in the Varg as era had motivations from several areas, where:

The civil bureaucracy defended the industrialization program as it was the path to the country's true independence; the 
military because they believed that installing a base industry would strengthen the economy - an important component of national security; industrialists because they would end up convincing themselves that the incentive to industrialization depended on an active intervention by the State

The Manifest of the Pioneers of New Education gave a direction for teaching.

Proponents of educational reform were deeply divided, based on ideological and doctrinal principles, ranging from authoritarian fascists (Francisco Campos) and ultramontane Catholic (Alceu Amoroso Lima), to American-type pragmatists (Anísio Teixeira) and those who believed in the scientific powers of the new pedagogy (Lourenço Filho and Fernando de Azevedo), reaching the Marxists (Paschoal Lemme). (Schwartzman, 2005, p, 23).

The renovation proposal faced the Catholic Church, which was responsible for the supervision and direction of teaching, supported by an agreement with Vargas. However, what prevailed in the end was Capanema's bureaucratic perspective, with a nationalist and conservative tone. Brazilian industrialization was consolidated supported by this strong nationalist policy.

It is worth remembering that concomitantly with the implementation of these actions in force, there was a movement towards urban centers. According to Oliveira (2003), in 1940, 27.4\% of Northeasterners chose to migrate to São Paulo due to the advancement of industry and better living and working conditions. Alves et al. (2011) highlights that the rural exodus between the $1950 \mathrm{~s}$ and $2010 \mathrm{~s}$, where in the 1950 s to $1960 \mathrm{~s}, 16.34 \%$ of the rural population migrated to large urban centers, especially in the Southeast region, which is considered the cradle of the industry. and until then the Republic's Headquarters. In later decades, between the 1960s and 1970s, there was an increase in the exodus, accounting for $22.85 \%$ of the internal migratory flow, reaching its apex in the 1970 s to 1980 s, with $30.02 \%$ of the rural contingent migrating to large urban centers. urban.

However, the educational processes in Brazil went back to the Schools of Apprentice Craftsmen in the 1910s, which took on a new model of education in the 1930s, the beginning of the transition to an economy based on industry, considering the recent entry into the capitalist system in Brazil and the real need for change in educational bases, being that decade, initiated by the foundation, in 1924, of the Brazilian Education Association (Associação Brasileira de Educação), brought to light the concepts of Escola Nova, proposing new values to Education and to the process of economic development (Andreotti, 2006) .

As we have seen, national education began to be debated at the beginning of the 20th century. In this movement, it strengthened its connection with the State plan. For an industrialized country it was necessary to train the workers. Public education promoted the basic teaching of reading, writing and counting, favoring the fulfillment of the minimum required by the job market. Factories employed many people, and many provided education and health care for their workers and their families. The objective of high school until the 1970s was to train people capable of handling machines and directing production processes (Castro \& Tiezzi, 2005). In other words, in Brazil, for a long period, the idea of monoculturalism prevailed as an ideal of formatting everyone in a uniform way.

After the Second World War, in the government of President Juscelino Kubitschek (1956-1961), unlike the previous political plan, foreign capital was welcomed and seen as valid support for development. Several local companies lose their competitive power and succumb. High-tech industries did not receive as much investment, which hampered their development.

The worker's subjectivity was designed for the development of the country (Araujo, 2012). Regarding the issue of subjectivity at work, Dejours (2005) portrays the need to know the subjective experiences involved in the collective body of workers in organizations. Therefore, the importance of analyzing the assumptions of psychic components in the real experience of work is highlighted, defending the idea that human integrality cannot be analyzed only from the objectivist perspective of 
behavior.

This period was characterized by the tension between individual subjectivity and collective subjectivity propagated by the State, fueled by social inequalities. In this process of subjectivation, Silva (2014) highlights three enunciative contexts about national identity in the 20th century, the first with the whitening policy of the eugenics movement in the first three decades, the second with the ideology of the supposed "racial democracy", and the third, contesting the fallacy of this democracy from the 1950 s onwards. Conforti (2017) praises the workers' struggle as a confrontation with authoritarian paternalism. Labor rights were conquered and not the result of concessions, although with a different tone in the populist discourse. All these factors together strengthened a symbolic split that led to decontextualization and the strengthening of individualization under the aegis of meritocracy, without revealing the agreements and indications as a bargaining chip.

\subsection{Industry 3.0 \& Education 3.0}

The Third Industrial Revolution began in the second half of the 20th century, a period between 1960-1990, called the Technical-Scientific Revolution, or Digital Revolution (Hermann et al., 2015). The production system has become technological, characterized by computing, digitization, telecommunication, robotics, and other electronic equipment. It was called the Information Age when Information and Communication Technology (ICT) came into production.

At this stage, Brazil was experiencing the period of the military regime in Brazil, which lasted from 1964 to 1985 , characterized by the centralization of power and a technicist development project. This period was marked with a large inflow of foreign capital, several multinational companies set up their bases in the country, this period became known as "Economic Miracle". To this end, agreements were signed by the Ministry of Education and Culture (MEC) and the United State Agency for International Development (USAID). Law 5,692/71 brought together primary education with the gymnasium and secondary education with the technician to equalize the school in a company standard. This change is based on the principle of terminality in which each level of education has a specific training objective.

The Brazilian Literacy Movement (Movimento Brasileiro de Alfabetização - MOBRAL) sought to face the high amount of illiteracy that charged a high price for the country's development, but unfortunately had low performance. Although it was justified in the Freirean method, there was a fundamental difference from its original purpose, an emptying of ideological content (Friendrich et al., 2010). Freire's pillar is emancipation through a critical reading of reality accompanied by a political stance.

Teacher training was guided by the idealization of homogenization of education, serving a restricted number of students, still assuming a position of social prominence. As there was the expansion of the right to education for all, the teaching position is declining and emptying, and their training is becoming increasingly lighter.

Over time, the teacher was being pressured by results and his practice questioned, as if the result of his professional action could be decontextualized. The number of students increased, the time decreased, as well as the focus of their specific educational action. Increasingly, the idealized educational success came to mean social ascension, with the relationship of entering good jobs. In the "witch hunt", the teacher as the center of education was also considered to be primarily responsible (Borges \& Cecílio, 2018).

Araújo (2012) describes that, in the mid-1970s, speculative capital competes with production capital. The Welfare State is no longer sustainable and neoliberal economic policy is increasingly structured. Even with advances in information technology and machinery, the worker is still needed. Entrepreneurship starts to be valued, as well as characteristics such as: competence, ability, proactivity, competitiveness, daring. This new subjectivity seeks to co-opt the worker turned towards himself, weakening the collective organization.

The period between the 1980s and 1990s is marked by two main aspects: 1) a long period of recession and economic 
stagnation; 2) Movement to re-democratize the country and rescue citizenship. In this climate of indignation, mobilization and popular participation, educational debates emerged focusing on the critical analysis of the school and its social function that repeated the deep-rooted historical inequalities. Topics such as: learning and human development are discussed; relationship between teacher and student; learning theories and educational processes. The universalization of education in the country becomes the focus of study, some theories stand out: a) Non-critical theories and critical-reproductive theories; b) Liberating Dialogical Education (Paulo Freire) and Active Pedagogies, such as constructivism and socio-interactionism.

The Brazilian economy underwent major changes in the 1990s, with privatization (partial of state-owned sectors), a process of denationalization of industry, increased automation and industrial productivity, globalization, and the opening of the domestic market. To improve competitiveness, with greater productivity and quality, this situation has driven technological modernization. There was a parallel result of industrial unemployment. Industrial companies that harmed human health in cities were forced to relocate and initiate environmental protection actions. A new industrial profile begins to be outlined in line with global movements, for example, based on the climate discussion.

Castro and Tiezzi (2005) indicate a new cycle of Brazilian education in the 1990s, with the democratization of access to primary education and the expansion of secondary education, accompanied by a comprehensive assessment system and curriculum reform. Teaching was generally elitist and exclusionary, which did not match the democratizing spirit of the time. Vocational secondary education was very weak, in fact, it did not professionalize, it only taught general primary content. The goal "education for all" directed the concept of basic education, which began to understand, in addition to elementary school, high school. Secondary education could be propaedeutic (prepare for the following levels) and/or vocational, that is, it had two proposals, which could be concomitant, complementary or supplementary, but not competing. Education was committed to developing competencies, skills, and content in a contextualized way, not in a reproductive way based on the accumulation of information.

Conforti (2017) relates the worsening of labor market indicators in the 1990s to the policy of reducing wage costs for companies. Borges and Cecílio (2018) observe precariousness in the context of Brazilian (re)democratization, with low wages and inadequate working conditions. The authors point out that in the 1980s and 1990s, teachers were immersed in a contradictory social context and incorporated these contradictions.

The worker's subjectivity influenced by the entrepreneurial ideal was configured in an individualistic and competitive view. The meritocratic discourse narrowed the discussion to personal effort and emptied the critical analysis of the sociohistorical, political and economic context. The prevalence of the discourse of education for all brought the subliminal message that everyone had the same right and those who were not successful had their own responsibility for this. Social contradictions and inequalities were superficially questioned. The curriculum disconnected from daily life and the work environment was discouraging for many. The positions of "competent or not to learn" and for the continuity of studies were introjected.

The precariousness of living and working conditions, more than staying, became generalized, through different forms of implicit and explicit violence, which need reflection in order to face them (Borges \& Cecílio, 2018). Subjectivity marked by immediacy and consumerism fed on critical dullness, which does not favor the development of abstract and autonomous thinking.

\subsection{Industry 4.0 \& Education 4.0}

The Fourth Industrial Revolution began in the 21st century, from 2000, known as the Technical-ScientificInformational Revolution. This period is characterized by globalization, interconnectivity, more modern means of communication and information. The fusion of physical, digital and biological reality with the demand for highly specialized training and a more ubiquitous and mobile internet is observed. Although standardized production continues, the emphasis is 
on customization with the quest to meet customer demand. The ability to learn to learn makes it possible to constantly update the worker, as technological advances demand and create new knowledge and products.

The Industrial Revolution 4.0 is linked to: a) innovation and rapid change, b) new digital technologies, c) machinemediated relationships, d) new media and big data, e) interconnectivity, and f) socio-emotional skills. Social-emotional skills, known as soft skills, are constantly developed through interaction. The greater the diversity, the greater the chance of rich learning experiences. The expansion of thinking-feeling-acting is triggered in the encounter with the difference that allows negotiation of meanings, co-construction of knowledge, vision of the whole and multiple identity formation. Being open to encounter is a dialogical exercise in self-knowledge, critical positioning and decision making. This is the true meaning of learning. Literacy demanded in this context is not just related to the basics of reading, writing, and counting. Technological, data and sociability literacy are sought after (Schwab, 2016). Rahman et al. (2019) discuss the importance of technology literacy and data literacy. This learning provides educational elements that prepare the teachers and students involved to deal with the new demands and the amount of information produced with high speed. Teachers are responsible for fostering a balance between technological advancement and national cultural strength.

The authors categorize technological literacy into four levels: functional (knowing how to operate a computer), conceptual (knowing how to search for information on the network), evaluative (differentiating the most suitable software for their needs) and critical (using it wisely, effectively and efficiently). For them, teachers and future teachers should be at the last level. As for data literacy, it is the ability to handle and transform information into knowledge, analyze it quantitatively and qualitatively.

The discussion on intellectual training and professional training needs to be reviewed and expanded to meet the advancement of Digital Information and Communication Technologies. Schwab (2016) argues that we are experiencing the fourth revolution based on three characteristics: speed (interconnectivity), breadth and depth (digital revolution associated with other technologies), and systemic impact (transformation in relationships). For the author, we are in the process of changing our style of doing (what and how) and of being (constitution of the self and perception of reality). He highlights that we are experiencing a paradigm shift, human production is recognized and enhanced by cognitive capacity. This is a period of major ongoing social changes that affect the way we learn, work, communicate and travel, for example. In this perspective, the author discusses the influence of the educational system on the social structure, articulating the ideals of democracy, citizenship, and isonomy. And for the development of cognitive and socio-emotional skills. Highlight for: a) physical and psychological wellbeing, b) team spirit and collaboration, c) criticality, d) creativity, e) empathy, f) initiative and proactivity, g) conflict mediation, h) action in emergencies, i) resilience and j) communication and different languages, which humanizes us through the recognition of uniqueness, mutuality, and respect for diversity. For its implementation, new teaching modalities must be incorporated, such as blended learning and active methodologies in their different formats: Project Based Learning, Problem Based Learning, Experiential Learning, Co-construction, Gamification, Inverted Classroom. In this perspective, the student must assume the leading role, and the teacher-educator, the mediation of learning.

Delors (1998), at the service of UNESCO, points out the structural axes for contemporary society based on four pillars of education: learning to be, learning to do, learning to live together, learning to learn. Siqueira Júnior (2007), based on the differentiation between information and knowledge, points to the importance of critically reading information. Machines can produce a huge volume of data _ Big data _ but it is necessary to know how to interpret and use them effectively and ethically. Castells (1999) brings in his writings the statement that:

i. format a national competency model for industry 4.0 to help companies and professionals on this new path, enabling course supply and demand, through a proposed national basis; 
ii. link the national model of competences for industry 4.0 in different training itineraries, in the structures of public and private educational provision;

iii. to model a "fund" for robotization and re-training of workers as a way of mitigating the impacts on employment, applied to at least 5 thousand workers, in an experimental way [...] (Brasil, 2017, p.28).

Schwartzman (2005) argues that nowadays there is no more difficulty in classroom numbers, since there are plenty of them. For the author, the issue lies in the low quality of education, high repetition rate and high dropout rate, especially among adolescents. He justifies his argument based on the difficulty of teaching the teacher to teach those who fall behind in the educational path and the choice of content without relevance. He highlights the great inequality of access to quality education, with the poorest part being the most affected. As for the dilemma between general education and vocational education, he raises the question: "Is the student learning what he needs to improve his personality and enter the job market? (Schwartzman, ibid, p.13).

Borges and Cecílio (2018) comment on the impossibility of education aimed at the information society without connection and without the implementation of advanced technologies in a generalized way, as the discrepancy in access and use of technologies increases social, cultural and economic inequality between people. Silva (2020) states that education needs to act with defined social objectives.

Friedrich et al. (2010) reveals that the progressive discourse based on the logic of the market attributed to education the socio-economic development of the citizen, emptying the educational obligations of government agencies. In tune with a productivist conception, it directly relates social and cognitive skills to the required professional profile.

Soup et al. (2020) pointed out positive and significant results in the influence of hard skills and soft skills with an increase in the innovation capacity of employees, mediated through organizational learning. However, the Brazilian educational routine still seems a distant example of this academic reality advocated by Education 4.0.

The subjectivity extolled in the Education 4.0 proposal is the investment in the movement of learning to learn, innovation and creativity, to favor the development of abstract thinking. However, the distance between individual subjectivity and subjectivity in discourses increases in line with the expansion of social, cultural and technological inequality. Having access to information is the minimum, but not the necessary for it to be transformed into knowledge. Self-knowledge, selfconcept and self-management are developed internally in the exercise of collective coexistence and negotiation.

\section{Critical View on the Industrial Revolution 4.0 and its Impact on Education as a Citizen's right}

The existence of the New Age must not make people forget their ethnic culture and national identity. (Rahman et al., 2019, p. 190).

Through the proposed historical course, one can observe how the psychological, social, political, and economic factors are intertwined. This position as a colonized remains in the Brazilian social imagination. The State plan committed to democracy and socio-political maturity of its people values ethnic culture, strengthens national identity, options that can be seen in investments that strengthen this ideal, mainly aimed at its population with precarious personal resources that puts it in a position of vulnerability.

The project of subjectivity implicit in the Education 4.0 proposal points, at least in theory, to libertarian education, but which is emptied if it is not based on democratic education sustained in a long-term political project. Words alone don't change scenery. For Santos (1991) overcoming the tension between subjectivity and citizenship is only possible through emancipation 
and not through State regulation. Concomitantly with the advance in digital technology, it is necessary to advance in social technology that strengthens the local personal and social identity.

Technological disruption can contribute to the country's development, as well as worsen its social inequalities. So that the negative aspects do not prevail, it is necessary, in addition to government actions, citizen commitment in choosing the direction that the country will take. The social fabric is formed in the permanent tension between individual subjectivity and the collective subjectivity of the State (Santos, 1991) and in the tension present in the negotiation of beliefs, interests, and societal values between different social actors. In the democratic State, an equitable distribution of power is sought in this negotiation.

The citizen awareness present in the educational goals, recognizes that no social action is neutral and encourages the participation of society to achieve social justice. This participation must be equitable, since social equality is illusory (Saes, 2001). Santos (1991) warns that the influencing factors in the subjective constitution can hinder or favor critical positioning, depending on the regulation exercised. Following his assumption, Gouvêa (2009) reaffirms the search for the balance of regulation through emancipation, marked by moral, cognitive and aesthetic rationality. Emancipation indicates the true need and social reality.

Sartori et al. (2018) draw attention to the fact that the Brazilian project steeped in a neoliberal vision is accompanied by social inequality, with new labor relations that take away workers' rights, in addition to economic, institutional, and political crisis. Although Industry 4.0 emerges as a natural way to increase the sector's competitiveness through digital technologies, few national industries have already entered this revolution.

According to Frigotto (2019), Revolution 4.0 is related to the re-edition of the logics of bourgeois revolutions, with the updating of inequalities, in which the worker is excluded and held responsible for his condition. Some criticisms and unintended consequences of this phase are: a) low human interactional quality; b) weakened identity; c) attacks on privacy; d) exacerbated consumerism; e) mismatch between time dedicated to leisure and work; f) individualistic, competitive positions; g) ethical fragility; h) increase in income concentration, unemployment and social inequality; i) fragmentation of the collective feeling; h) loss of labor rights conquered collectively and democratically; $j$ ) increase in the disadvantaged population of government apparatus and growth of informal and self-employed workers.

The dichotomy between what is proclaimed in the legislation versus the reality of digital desertion, despite the figures presented by the Ministry of Communications, highlights data from the PNAD-Continuous (National Program of Samples by Continuous Households), with an increase in access to internet services in the country, where $82.7 \%$ of households already have access to data services, however, the form of access is still a limiting factor, especially for study purposes, given that despite the growing data on access to the world wide web, not all households have computers for internet access, and this number continues to fall.

The study by the Regional Center for Studies for the Development of the Information Society (Centro Regional de Estudos para o Desenvolvimento da Sociedade da Informação- CETIC) aims to "cooperate with Latin American and Portuguese-speaking countries in Africa to build inclusive knowledge societies" (CETIC, 2021). This center highlights that the greater use of services is accessed by cell phone and that training activities are not the core of user research, especially for the economically less favored classes, which points out that the destination for studies and work with internet use is occupied by a large part by people who are in class A (60 and 66\%, respectively), compared to a lower percentage presented by classes D and $\mathrm{E}$, who use the internet for studies in $27 \%$ of cases and for professional activities, $18 \%$.

Given the above, it is worth reiterating the considerations of the Freire ideology (1996) in its conception of respect for the subjectivity of the subject and the mediation of the processes of construction and/or reconstruction of knowledge. Therefore, an education based on the experience and construction of the individual's autonomy is revealed, where, in adult 
education, what drives learning is the overcoming of challenges, the resolution of problems and the construction of new knowledge from knowledge and knowledge. previous and democratic experiences of individuals. In defense of the subjective exercise of a libertarian education, the ideas of Dewey (1959) and Freire (1996) share the importance of stimulating the development of a pedagogy, also problematizing, in the conception of a mutual learning (construction and reconstruction of knowledge) between mediators and students in formally or informally constructed learning spaces. This, aiming at the subject's intellectual autonomy to intervene in the reality.

Didactic modernization is not limited to the use of new Digital Information and Communication Technologies - TDIC (acronym in Portuguese) and new audiovisual languages, since the technique needs to be preceded by the purpose and critical reading of reality, but also without technological advancement embedded in education, we won't get to phase 4.0 well. New technologies can be used within an obsolete model of human development, that is, one that excels in repetition and not critical updating of school contents. It is not enough to implement only educational reforms; it is necessary to read the full meaning of the notion of revolution in education. If having the equipment doesn't guarantee the quality of the work, not having access to any equipment really ends any possibility of digital literacy. Barroso Filho (2021) defends a great national pact in favor of Education, and in this way, collaborate with the fight against social inequality.

The education that recognizes the student as the main actor in the process of his/her formation, stands out for the reflexive and autonomous vision of himself and the world, and assumes a clear position at the intersection with the world of work. Self-assessment associated with a critical reading of reality contributes to awareness (Freire, 1996) and proactivity. Inspired by Mogilka (2010), we can infer that when libertarian education breaks the division between lay and scientific and/or elaborate knowledge, it enhances the symbolic movement of meaning construction/negotiation. The emancipating mediator is then committed to the formation of the critical and reflective subject, author of his thoughts, and engaged in planetary consciousness (Corrêa, \& Barbosa, 2018).

A cultural revolution is needed that influences the exercise of citizenship, so idealized in Education 4.0. We can recognize its effective valorization in the following aspects: a) social, with the improvement in interactions through greater flexibility and adaptability, resilience, persistence and proactivity, expansion of social and cultural awareness, development of leadership skills; b) cognitive, with the exercise of authorship and autonomy of thought, agility of research design and problem solving, critical thinking skills, space for criticism and creativity, experience of horizontal and clear communication, with receipt of feedbacks, co-construction knowledge and collaborative management; c) digital civic participation, with identification and engagement in social groups, use of TDIC in promoting, defending and fighting for rights, critical and constructive positioning in social reality.

Education 4.0, to effectively contribute to the construction of a fairer and more conscious society, needs to consider the value of subjectivity not as something to be managed in favor of capital, but as a result of a negotiation of interests in which the quality of life within an ethical perspective is the common starting point. It is not possible to get rich at the expense of someone else's poverty. This new educational perspective, if it reflects ethically on the encounter between libertarian human subjectivity and technology, can collaborate with the maturity of planetary consciousness. Critical reflection is meant to be done by everyone, from self-criticism to social criticism.

\section{Conclusion}

The objectives were achieved, the socio-historical path in the intertwining between industry and education in phases $1,2,3$ contributed to the analysis of the value of subjectivity in phase 04 .

The constitution of subjectivity is a dynamic process crossed by intrapersonal and interrelational aspects. The human being as an active subject in the creation of reality influences and is influenced by the socio-historical context. In this way, the 
panorama of the connection between Industry 4.0 and Education 4.0 and subjectivity does not occur in a linear way, but has impacts on personal and professional training. Although social pressures present in values, beliefs and policies exert great power in opportunities and incentives towards human development, they do not determine it. When the subject becomes aware of the manipulative forces of hegemonic power, he is strengthened in the process of symbolic negotiation and social organization. Human beings can build mental tools for their emancipation and collective articulation and not submit to oppression.

Education may or may not be liberating, depending on its principles. It is oppressive when it serves to maintain the hegemonic power of control that some exercise in the majority, to maintain social inequality, guarantee the privileges of their status quo and obtain their own benefits. Liberating education is one that provides opportunities and encourages emancipation and democratic participation, which recognizes and commits to respect for diversity and individual and collective human rights.

For the ethical and social purposes of education 4.0 to be effective, in line with the appreciation of human creativity and innovation defended by industry 4.0, it is necessary to break with what does not favor ethical, conscious, critical, and participatory positioning in an equitable way. Technological advancement must not diminish human potential, it must serve its evolution, a movement possible only when guided by social justice. We suggest further studies on how to positively articulate education and industry 4.0 .

\section{References}

Andreotti, A. L. (2006). O governo Vargas e o equilíbrio entre a pedagogia tradicional e a pedagogia nova. Grupo de Estudos e Pesquisas "História, Sociedade e Educação no Brasil". Faculdade de Educação. UNICAMP. Coleção "Navegando pela História da Educação Brasileira". <https://www.histedbr.fe.unicamp.br/navegando/artigos/o-governo-vargas-e-o-equilibrio-entre-a-pedagogia-tradicional-e-a-pedagogia-nova>.

Araújo, J. N. G. (2012). Trabalho e usos da subjetividade. Arquivos Brasileiros de Psicologia. 64(2), 35-46. <http://pepsic.bvsalud.org/pdf/arbp/v64n2/v64n2a04.pdf>.

Arquivo Nacional. (2021[1785]). Alvará de D. Maria I que proíbe o estabelecimento de fábricas e manufaturas no Brasil. 05 de janeiro de 1785 . Junta da $\begin{array}{llllll}\text { Fazenda da } & \text { província } & \text { São } & \text { Paulo. }\end{array}$ http://historiacolonial.arquivonacional.gov.br/images/media/Junt\%20da\%20fazend\%20COD439\%20f27f27vf28.pdf.

Barreto, A. C. (2016). Paradigma Sistêmico no desenvolvimento humano e familiar: a teoria de Urie Bronfenbrenner. Psicologia em Revista, 22(2), 275-293. <http://pepsic.bvsalud.org/pdf/per/v22n2/v22n2a03.pdf>.

Barroso Filho, J. (2021). Educação e suas pandemias: quando o vírus do passado contamina o futuro. Estadão.

Borges, E. F., \& Cecílio, S. (2018). O Trabalho Docente no Brasil [década de 1950 aos dias atuais]: a precarização no contexto de (re)democratização. Holos, 5, 177-194. <https://www2.ifrn.edu.br/ojs/index.php/HOLOS/article/view/6535>.

Brasil. (1988). Constituição da República Federativa do Brasil. <https://www.senado.leg.br/atividade/const/con1988/con1988_05.10.1988/ind.asp>.

Brito, S. H. A. (2006). A educação no projeto nacionalista do primeiro governo Vargas (1930-1945). Grupo de Estudos e Pesquisas "História, Sociedade e Educação no Brasil". Faculdade de Educação. UNICAMP. Coleção "Navegando pela História da Educação Brasileira". <http://www.histedbr.fe.unicamp.br/navegando/periodo_era_vargas_intro.html>.

Bronfenbrenner, U., \& Morris, P. A. (1998). The ecology of developmental processes. In: Damon, W., Lerner, R. M. (Orgs.). Handbook of child psychology, Vol. 1: Theoretical models of human development. John Wiley, 993-1028.

Castells, M. (1999). A sociedade em rede. Paz e Terra.

Castro, H., \& Tiezzi, S. (2005). A reforma do ensino médio e a implantação do ENEM no Brasil. In Schwartzman, S., Brock, C. (org.). Os desafios da educação no Brasil. Nova Fronteira.

CETIC. (2021). Centro Regional de Estudos para o Desenvolvimento da Sociedade da Informação. Home. Página de apresentação do site. <https://www.cetic.br/>.

Conforti, L. P. (2017). A Interpretação do Conceito de Trabalho Análogo ao Escravo no Brasil: O Trabalho Digno sob o Prisma da Subjetividade e a Consciência Legal dos Trabalhadores. Anais XXVI Encontro Nacional do Conpedi. <https://www.anamatra.org.br/files/ConpediFINAL.pdf>.

Corrêa, T. H. B., \& Barbosa, N. A. P. (2018). Educação ambiental e consciência planetária: uma necessidade formativa. REMEA - Revista Eletrônica do Mestrado em Educação Ambiental, 35(2), 125-136, 10.14295/remea.v35i2.7692. https://periodicos.furg.br/remea/article/view/7692. 
Dejours, C. (2005). O Fator Humano. Tradução Maria Irene Stocco Betiol, Maria José Toneli. Editora FGV.

Delors, J. (1998). Os quatro pilares da educação. In: Educação: um tesouro a descobrir. Cortez.

Dewey, J. (1959). Interesse e esforço. In: Vida e Educação. Companhia Editora Nacional.

Freire, P. (1996). Pedagogia da Autonomia: saberes necessários à prática educativa. Paz e Terra.

Friedrich, M., Benite, A. M. C., Benite, C. R. M., \& Pereira, V. S. (2010). Trajetória da escolarização de jovens e adultos no Brasil: de plataformas de governo a propostas pedagógicas esvaziadas. Ensaio: avaliação e políticas públicas na Educação, Rio de Janeiro, 18(67), 389-410, https://doi.org/10.1590/S010440362010000200011 .

Furtado, M. B., Pedroza, R. L. S., \& Alves, C. B. (2014). Cultura, identidade e subjetividade quilombola: uma leitura a partir da psicologia cultural. Psicologia \& Sociedade. 26(1), 106-115, <https://doi.org/10.1590/S0102-71822014000100012>.

Gotardo, C. A., \& Favaro, N. A. L. G. (2019). Escola pública: origens e funções no período da revolução industrial inglesa. Horizontes - Revista de Educação, 7(13), 37-54. https://ojs.ufgd.edu.br/index.php/horizontes/article/view/9122.

Gouvêa, C. B. (2009). Subjetividade, Cidadania, Pessoas Constitucionais e emancipação: Conceitos Adversos que Necessitam Maior Compreensão. Seara Jurídica. 2, 63-71. <http://web.unijorge.edu.br/sites/searajuridica/pdf/anteriores/2009/2/searajuridica_2009_2_pag63.pdf>.

Harouche, C. (2009). Reflexões sobre a subjetividade na colonização. Conexão $\quad$ Letras. <https://seer.ufrgs.br/conexaoletras/article/download/55581/33791>.

Hermann, M., Pentek, T., \& Otto, B. (2015). Design Principles for Industrie 4.0 Scenarios: A Literature Review. Working paper, $\mathrm{n}^{\mathbf{0}} 1 / 2015$. Technische Universität Dortmund Fakultät Maschinenbau Audi Stiftungslehrstuhl Supply Net Order Management. https://www.researchgate.net/publication/307864150_Design_Principles_for_Industrie_40_Scenarios_A_Literature_Review.Acesso em 31/07/2021.

Mogilka, M. (2010). A mediação na educação popular e seu impacto na subjetividade. Extensão em Foco, 6, 101-111, <https://revistas.ufpr.br/extensao/article/view/32118/20421>.

Mometti, C. (2021). O saber necessário à prática docente na humanidade digital. Revista de Educação Matemática, 18, e021010, 24 <http://revistasbemsp.com.br/index.php/REMat-SP/article/view/482>.

Rahman, A. W. S. R., Widya, R. N., \& Yugafiati, T. R. (2019). Elementary Education Literacy in the Era of Industrial Revolution 4.0. Advances in Social Science, Education and Humanities Research, 257. UPI 2nd International Conference on Language, Literature, Culture and Education (ICOLLITE 2018). 190193. <https://www.atlantis-press.com/proceedings/icollite-18/55915098>.

Ribeiro, J. L. P. Revisão de Investigação e Evidência Científica. (2014). Psicologia, Saúde \& Doenças. 15(3), 671-682. https://www.redalyc.org/pdf/362/36232744009.pdf.

Saes, D. A. M. (2001). A questão da evolução da cidadania política no Brasil. Estudos Avançados. 15(42), 379-410. <https://www.scielo.br/j/ea/a/4tXzWL8S6w3q59BHL4Pc99h/?format=pdf\&lang=pt>.

Santos, B. S. (1991). Subjetividade, Cidadania e Emancipação. Revista Crítica de Ciências Sociais, 32, <https://www.ces.uc.pt/publicacoes/rccs/artigos/32/Boaventura\%20de\%20Sousa\%20Santos\%20-

$\% 20$ Subjectividade, $\% 20$ Cidadania\%20e\%20Emancipacao.pdf $>$.

Sartori, G., Zanotto, M. P., \& Fachinelli, A. C. (2018). Liderança em Tempos de Indústria 4.0: Novos Papéis para um Novo Perfil? XVIII Mostra de Iniciação Científica, Pós-graduação, Ensino e Extensão. Programa de Pós-graduação em Administração. UCS. <http://www.ucs.br/etc/conferencias/index.php/mostraucsppga/xviiimostrappga/paper/viewFile/6022/1963>.

Saviani, D. (2007). O pensamento pedagógico brasileiro: da aspiração à ciência sob suspeição. In: Educação e Filosofia, Uberlândia. 21(42), 13-35, http://www.seer.ufu.br/index.php/EducacaoFilosofia/article/view/463/445.

Schwab, K. S. (2016). A Quarta Revolução Industrial. Edipro.

Schwartzman, S. (2005). Os desafios da educação no Brasil. In: Schwartzman, S., Brock, C. (org.). Os desafios da educação no Brasil. Rio de Janeiro: Nova Fronteira.

Siqueira Junior, P. H. (2007). Direito informacional: direito da sociedade da informação. Revista dos Tribunais, 96(859), 743-749.

Silva, F. G. (2009). Subjetividade, individualidade, personalidade e identidade: concepções a partir da psicologia histórico-cultural. Psicologia da Educação, São Paulo, 28, $1^{\circ}$ sem., 169-195. <http://pepsic.bvsalud.org/pdf/psie/n28/v28a10.pdf>.

Silva, M. L. (2014). Biopolítica e espaço escolar: subjetividade e racismo no Brasil. Horizontes. USF. 32(2), 111-122, <https://revistahorizontes.usf.edu.br/horizontes/article/download/94/49>.

Silva, R. A. (2020). Educação 4.0 para a Indústria 4.0: Protagonismo do Avanço Social no Cenário Introduzido pela Sociedade da Informação. Boletim Piauí. Primeira à Última Infância. Núcleo Estudos do Futuro. Programas de Pós-Graduação em Economia e Administração da PUC-SP. <https://www5.pucsp.br/catedraignacysachs/boletim-piaui/artigo-2-piaui.pdf>.

Sopa, A., Asbari, M., Purwanto, A., Santoso, P. B., Mustofa, Hutagalung, D., Maesaroh, S., Ramdan, M. \& Primahendra, R. (2020). Hard Skills versus Soft Skills: Which are More Important for Indonesian Employees Innovation Capability. International Journal of Control and Automation. 13(2), 156-175. https://www.researchgate.net/profile/Agus-Purwanto-10/publication/340412466_Hard_Skills_versus_Soft_Skills_Which_are_More_Important_for_Indone sian_Empl_oyees_Innovation_Capability/links/5e979b2aa6fdcca7891c232f/Hard-Skills-versus-Soft-Skills-Which-are-More-Important-for-IndonesianEmployees-Innovation-Capability.pdf. 